UDK 574.587:582.26/.27(234.422 Konjuh)

\title{
COMPARATIVE ANALYSIS OF EPILITHIC DIATOM ASSEMBLAGES OF SPRINGS AND STREAMS IN THE KONJUH MOUNTAIN (BOSNIA AND HERZEGOVINA)
}

Komparativna analiza epilitskih dijatomejskih zajednica u izvorima i potocima planine Konjuh (Bosna i Hercegovina)

\author{
Jasmina Kamberović $^{1}$, Amela Kišić ${ }^{2}$, Dubravka Hafner ${ }^{3}$, Anđelka Plenković-Moraj ${ }^{4}$
}

\begin{abstract}
Springs are recognized as hotspots for freshwater biodiversity conservation. The study objective was to analyze and compare the biodiversity of epilithic diatom communities of spring and stream habitats in the Konjuh Mountain $(\mathrm{B} \& \mathrm{H})$. The measuring of basic water physical and chemical parameters and diatom sampling were carried out during summer and autumn period in 2013.

Diatom assemblages were collected from 10 locations: (i) five locations were placed in small mountain springs that flow into headwater streams, where another 5 localities were placed. Diatoms were collected by scrubbing the rocks using standard methodology. Relative diatom cell abundances were established by counting up to 400 frustules on permanent slides prepared in Naphrax.

Spring habitats were more diverse in diatoms $\left(H^{\prime} \log _{\mathrm{e}}=1.67\right.$ average $)$ in comparison with headwater stream habitats $\left(H^{\prime} \log _{\mathrm{e}}=1.15\right.$ average $)$, which was confirmed by $t$-test $(t=2.79 ; p=0.013)$. The similarities of community structure from different habitats were investigated by non-metric multidimensional scaling, on the Bray-Curtis similarity matrix in software package Primer 6.

Using Permutational Manova test, a different diatom composition was proved between spring and stream communities (Pseudo $\mathrm{F}=2.66, p=0.012$ ), while the seasonal difference in the community structure was not confirmed $(\mathrm{F}=0.586, p=0.876)$. The most abundant and frequent species in spring habitats were: Achnanthidium minutissimum (Kützing) Czarnecki, Cocconeis pseudolineata (Geitler) Lange-Bertalot, Gomphonema pumilum var. elegans E.Reichardt \& Lange-Bertalot, Meridion circulare (Greville) C.Agardh and Planothidium lanceolatum (Brébisson ex Kützing) Lange-Bertalot. The most frequent and abundant species in headwater stream habitats were: Achnanthidium minutissimum (Kützing) Czarnecki, Cocconeis placentula var. euglypta (Ehrenberg) Grunow, Cocconeis placentula var. lineata
\end{abstract}

\footnotetext{
${ }^{1}$ University of Tuzla, Faculty of Science, Department of Biology, Tuzla, Bosnia and Herzegovina

${ }^{2}$ Public utility company 'Komunalac' Tuzla, Bosnia and Herzegovina

${ }^{3}$ University of Mostar, Faculty of Science and Education, Mostar, Bosnia and Herzegovina

${ }^{4}$ University of Zagreb, Faculty of Science, Department of Biology, Zagreb, Croatia
} 
(Ehrenberg) van Heurck and Cymbella tridentina Lange-Bertalot, M.Cantonati \& A.Scalfi.

In comparison with streams habitats, the springs are heterogeneous with specific diatom composition due to more stable water flow. Although the springs cover very small areas, the diversity of species that inhabit them must not be neglected in planning the use of these natural resources.

Key words: diversity, epilithic diatoms, springs, streams, habitats, Konjuh Mountain $(B \& H)$

\section{INTRODUCTION - Uvod}

Benthic or periphytic algae are very important primary producers in lotic ecosystems, and they are also very important biological indicators of water quality due to their possibility of rapid reproduction and quick response to environmental changes (LOWE and PAN 1996).

Depending on the colonized substrate type, periphytic algal communities are divided into: epilithic, epiphytic, epipsamic, and epipelic algal stream communities. According to STEVENSON (1996) epilithic algae are defined as those which grow on hard, relatively inert substrata, such as gravel, pebble, cobble, and boulder.

Recently, spring areas have been identified as important refuge for conservation of algal biodiversity (CANTONATI et al. 2012a), and investigations of these habitats have been intensified since the mid of the nineties (SABATER and ROCA 1990; CANTONATI 1998; ABOAL et al. 1998; Werum and LANGe-BERTALOT 2004; PouličKOVA et al. 2005; WOJTAL and SOBCZYK 2006; TAXBÖCK and PREISIG 2007; FRANKOVA et al. 2009; CANTONATI et al. 2012b, 2012c).

Several studies have focused on the research of the algal community structure in the spring - fed stream complex, such are those in Canada (SHERWOOD et al. 2000), in Texas in the USA (SHERWOOD and SHEATH 1998), in Majorca (DELGADO et al. 2013), in Adamelo Brenta region in Italy (CANTONATI and PIP 2000), in Dolomiti Bellunesi National Park in Italy (CANTONATI and SPITALE 2009). Crenal communities of algae and macrophytes are studied in spring habitats of the Konjuh Mountain in Bosnia and Herzegovina (KAMBEROvić 2015). However, diatom assemblages in stream epilithic habitats have not been compared with diatom assemblages in springs before. In general, researches of spring algal communities in Bosnia and Herzegovina are scarce and rare (BLAGOJEVIĆ 1974, 1976a, 1976b; KAPETANOVIĆ and HAFNER 2007; KAPETANOVIĆ et al. 2011; DEDIĆ et al. 2015).

The objective of this study was to analyze and compare the biodiversity of epilithic diatom communities of five spring and five stream habitats in the Konjuh Mountain in northeastern Bosnia and Herzegovina. 


\section{METHODS - Metode}

Diatom sampling was carried out in summer (July and August) and in autumn (October) by scrubbing the rocks (epilithon) from five to six cobbles in 2013 (KELLY et al. 1998). Samples were collected in the place where groundwater comes to the surface (5 spring localities), and in the places after the spring fed-streams flow into streams (5 stream localities). Samples were treated by concentrated sulfuric acid (HUSTEDT 1930), and cleaned valves were embedded in Naphrax. Light microscopes (Motic and Olympus BX41) and immersion objective (magnification 1000x) for the identification and quantification of algae were used. The determination of algae species was performed using the following sources: KRAMMER and LANGE-BERTALOT (1986; 1988; 1991a; 1991b), KRAMmer (2000; 2001; 2002), HofMANN et al. (2011). Nomenclature of species is in accordance with AlgaeBase (GUIRY and GUIRY 2016), and the base was accessed on 9 December 2016. Assemblages diversity was quantified with the Shannon - Wiener Diversity Index (logarithms to the base ln; SHANNON and WIENER 1949). Temperature, $\mathrm{pH}$ and conductivity were measured in situ using a Multimeter Hanna HI 9828. For statistical analysis, the method of non-metric multidimensional scaling (n-MDS) for spring ordering was used. The ordination was conducted on the Bray-Curtis similarity matrix of species data (LEGENDRE and LEGENDRE 1998). The data were transformed by square root to restrict the influence of abundant taxa on the results. Permutational Manova test (ANDERSON 2001) was used for the comparison of spring and stream diatom assemblages and IndVal analysis for detecting indicator species for spring and stream habitats (DUFRENE and LEGENDRE 1997). Statistical analyses were performed in Primer 6.0 (CLARKE and WARWick 2001) and PC ORD 5 (GRANDIN 2006).

\section{STUDY AREA - Područje istraživanja}

Konjuh Mountain is a part of the central Dinarides on the Balkan Peninsula, with altitude to $1326 \mathrm{~m}$ a.s.l.. It belongs to the moderate continental climate zone. The mean annual temperature varies from $9.2{ }^{\circ} \mathrm{C}-10.0{ }^{\circ} \mathrm{C}$, and the annual precipitation is from 900 to $1250 \mathrm{~mm}$ (according to the closest metereological station in Kladanj). The investigation was performed on five spring and five stream localities: Tarevo (TA), Miljevica (MI), Gluha Bukovica (GB), Katranica (KA) and Kesovača (KE).

\section{RESULTS - Rezultati}

\section{Ecomorphological characteristics of springs and streams}

Investigated springs and streams (Table 1) are located on altitudes ranging from 536 to $875 \mathrm{~m}$. a. $\mathrm{s}$. 1. The most of the studied springs are small rheocrene. As expected, water temperature was slightly higher in streams than in springs, and in the summer compared with autumn period. Moreover, $\mathrm{pH}$ of the water was weakly 
alkaline, and it had similar values compared investigated localities. Conductivity was moderately high (ranged between $123-387 \mu \mathrm{Scm}^{-1}$ ).

Table 1. Ecomorphological, physical and chemical characteristics of water and species diversity ranging from summer to autumn, $\mathrm{R}$ - rheocrenic springs, $\mathrm{H}-\mathrm{P}$ - hygropetric springs Tabela 1. Ekomorfološke, fizičke $i$ hemijske osobine vode $i$ specijski diverzitet u rangu vrijednosti od ljetne do jesenje sezone, $R$ - reokreni izvori, $H$-P - higropetrični izvori

\begin{tabular}{|c|c|c|c|c|c|c|c|c|c|c|}
\hline Locality & $\begin{array}{c}\mathrm{KE} \\
\text { spring }\end{array}$ & $\begin{array}{l}\mathrm{KE} \\
\text { stream }\end{array}$ & $\begin{array}{l}\text { MI - } \\
\text { spring }\end{array}$ & $\begin{array}{c}\text { MI - } \\
\text { stream }\end{array}$ & $\begin{array}{l}\text { TA - } \\
\text { spring }\end{array}$ & $\begin{array}{c}\text { TA - } \\
\text { stream }\end{array}$ & $\begin{array}{l}\text { GB - } \\
\text { spring }\end{array}$ & $\begin{array}{c}\text { GB - } \\
\text { stream }\end{array}$ & $\begin{array}{l}\text { KA - } \\
\text { spring }\end{array}$ & $\begin{array}{l}\mathrm{KA} \mathrm{-} \\
\text { stream }\end{array}$ \\
\hline \multirow[t]{2}{*}{ Coordinates } & \multicolumn{2}{|c|}{$44^{\circ} 18^{\prime} 43.52^{\prime \prime} \mathrm{N}$} & \multicolumn{2}{|c|}{$44^{\circ} 16^{\prime} 26.98^{\prime \prime} \mathrm{N}$} & \multicolumn{2}{|c|}{$44^{\circ} 19^{\prime} 6.67^{\prime \prime} \mathrm{N}$} & \multicolumn{2}{|c|}{$44^{\circ} 12^{\prime} 48.91^{\prime \prime} \mathrm{N}$} & \multicolumn{2}{|c|}{$44^{\circ} 14^{\prime} 56.84^{\prime \prime N}$} \\
\hline & \multicolumn{2}{|c|}{$18^{\circ} 32^{\prime} 8.10^{\prime \prime} \mathrm{E}$} & \multicolumn{2}{|c|}{$18^{\circ} 33^{\prime} 34.42^{\prime \prime} \mathrm{E}$} & \multicolumn{2}{|c|}{$18^{\circ} 38^{\prime} 59.19^{\prime \prime} \mathrm{E}$} & \multicolumn{2}{|c|}{$18^{\circ} 38^{\prime} 40.07^{\prime \prime E}$} & \multicolumn{2}{|c|}{$18^{\circ} 33^{\prime} 44.43^{\prime \prime E}$} \\
\hline $\begin{array}{c}\text { Flow } \\
\text { condition }\end{array}$ & $\mathrm{R}$ & $\mathrm{R}$ & H-P & $\mathrm{R}$ & $\mathrm{R}$ & $\mathrm{R}$ & $\mathrm{R}$ & $\mathrm{R}$ & $\mathrm{R}$ & $\mathrm{R}$ \\
\hline Flow type & $\begin{array}{l}\text { episo } \\
\text { dic }\end{array}$ & steady & steady & steady & steady & steady & $\begin{array}{l}\text { episo } \\
\text { dic }\end{array}$ & steady & steady & steady \\
\hline $\begin{array}{l}\text { Altitude } \mathrm{m} \\
\text { a.s.l. }\end{array}$ & 694 & 694 & 815 & 813 & 536 & 536 & 692 & 692 & 875 & 875 \\
\hline $\begin{array}{c}\text { Temperature } \\
{ }^{\circ} \mathrm{C}\end{array}$ & $\begin{array}{l}11.8 \\
-8.9\end{array}$ & $\begin{array}{c}12.07- \\
9.31\end{array}$ & $\begin{array}{l}11- \\
7.87\end{array}$ & $\begin{array}{l}18.5- \\
11.12\end{array}$ & $\begin{array}{c}9- \\
8.96\end{array}$ & $\begin{array}{c}12.85- \\
9.41\end{array}$ & $\begin{array}{c}8.5- \\
11.2 \\
4\end{array}$ & 11.24 & $\begin{array}{c}14.22- \\
8.73\end{array}$ & $\begin{array}{c}14.2- \\
8\end{array}$ \\
\hline $\mathrm{pH}$ & $\begin{array}{l}8.4- \\
8.7\end{array}$ & $8.3-8.8$ & $\begin{array}{c}8.74- \\
8.7\end{array}$ & $\begin{array}{l}8.4- \\
8.24\end{array}$ & $\begin{array}{l}7.3- \\
8.26\end{array}$ & $\begin{array}{l}7.77- \\
8.72\end{array}$ & $\begin{array}{l}7.52 \\
-9.3\end{array}$ & 9.3 & $\begin{array}{l}8.15- \\
8.81\end{array}$ & $\begin{array}{c}8.12- \\
8.8\end{array}$ \\
\hline $\begin{array}{c}\text { Conductivity } \\
\mu \mathrm{Scm}^{-1}\end{array}$ & $\begin{array}{c}181- \\
123 \\
\end{array}$ & $\begin{array}{c}190- \\
299\end{array}$ & $\begin{array}{c}265- \\
303 \\
\end{array}$ & $\begin{array}{c}251- \\
163 \\
\end{array}$ & $\begin{array}{c}401- \\
387 \\
\end{array}$ & $\begin{array}{c}313- \\
324\end{array}$ & $\begin{array}{c}371- \\
312 \\
\end{array}$ & 312 & $\begin{array}{c}249- \\
192 \\
\end{array}$ & $\begin{array}{c}237- \\
174 \\
\end{array}$ \\
\hline $\begin{array}{l}\text { Number of } \\
\text { species }(N)\end{array}$ & $6-7$ & $4-6$ & $9-3$ & 6 & $15-14$ & $6-4$ & $7-8$ & 8 & $11-9$ & $5-7$ \\
\hline $\begin{array}{c}\text { Shannon - } \\
\text { Wiener } \\
\text { Diversity } \\
\text { Index (H'ln) }\end{array}$ & $\begin{array}{l}1.11 \\
- \\
1.44\end{array}$ & $\begin{array}{c}1.15- \\
1.12\end{array}$ & $\begin{array}{l}1.56- \\
0.98\end{array}$ & $\begin{array}{l}1.12- \\
0.98\end{array}$ & $\begin{array}{l}1.92- \\
1.86\end{array}$ & $\begin{array}{c}1.32- \\
1.2\end{array}$ & $\begin{array}{c}1.74 \\
- \\
1.77\end{array}$ & 1.77 & $\begin{array}{c}1.77- \\
1.8\end{array}$ & $\begin{array}{c}0.34- \\
1.32\end{array}$ \\
\hline
\end{tabular}

\section{Diatoms}

A total of 50 diatom taxa were identified in 19 samples. The summer sample of stream GB was diatom empty, and it was excluded from statistical analysis. The total of 45 taxa in the samples of spring habitats, and 17 taxa in the stream samples were found. In spring habitats following taxa had abundance in average above 5\%, and frequency more than 50\%: Achnanthidium minutissimum, Cocconeis placentula var. lineata, Cocconeis pseudolineata, Gomphonema pumilum var. elegans and Planothidium lanceolatum. In stream habitats taxa with frequency more than $25 \%$, and abundance in average above 5\% were: A. minutissimum, Cocconeis placentula var. euglypta, Cocconeis placentula var. lineata, Cymbella tridentina, Gomphonema pumilum and Meridion circulare. The following species have been found exclusively in springs habitats: Amphora indistincta, Achnanthidium affine, Achnanthidium straubianum, Adlafia minuscula, Amphora copulata, Amphora ovalis, Brachysira sp., Cymatopleura solea, Humidophilla perpusilla, Diploneis krammeri, Encyonopsis cesatii, Eolimna minima, Navicula cryptotenella, Navicula antonii, Navicula tripunctata, Pinnularia subrupestris, Planothidium dubium, Planothidium 
frequentissimum and Sellaphora pupula. The following species have been found exclusively in stream habitats: Cocconeis placentula var. euglypta, Cocconeis pediculus, Cymbella tridentina, Encyonopsis krammeri and Epithemia frickei. The list of identified taxa and comparison of frequency and abundance of species in springs and streams is given in the Table 2.

Table 2. List of identified diatom taxa in springs and streams, species relative frequency, average abundance, and statistical significance $(p)$ of indicator value (IV) given by IndVal analysis for diatoms in the springs and streams, taxa with names in bold were more abundant or had tendency for one of the two researched habitats

Tabela 2. Popis identificiranih dijatomeja u izvorima i potocima, relativna frekvencija vrsta, prosječna abundanca $i$ statistička značajnost indikatorske vrijednosti dobijene IndVal analizom za dijatomeje izvorskih i potočnih staništa, taksoni sa boldiranim nazivima su češće zastupljeni ili imaju afinitet pojavljivanja za jedan od dva istraživana staništa 


\begin{tabular}{|c|c|c|c|c|c|c|c|c|}
\hline \multirow[b]{3}{*}{ Taxa } & \multirow{2}{*}{\multicolumn{2}{|c|}{ Relative frequency (\%) }} & \multicolumn{4}{|c|}{ Average abundance (\%) } & \multirow[b]{3}{*}{ IV } & \multirow[b]{3}{*}{$p$} \\
\hline & & & & \multirow[b]{2}{*}{$\begin{array}{l}\text { Stream } \\
\text { habitats } \\
\text { summer } \\
\text { samples }\end{array}$} & \multirow[b]{2}{*}{$\begin{array}{l}\text { Spring } \\
\text { habitats } \\
\text { autumn } \\
\text { samples }\end{array}$} & \multirow[b]{2}{*}{$\begin{array}{l}\text { Stream } \\
\text { habitats } \\
\text { autumn } \\
\text { samples }\end{array}$} & & \\
\hline & springs & streams & $\begin{array}{l}\text { Spring } \\
\text { habitats } \\
\text { summer } \\
\text { samples }\end{array}$ & & & & & \\
\hline $\begin{array}{l}\text { Achnanthidium affine (Grunow) Czarnecki } \\
\text { Achnanthidium linearioides (Lange-Bertalot) }\end{array}$ & 10 & & 1.1 & & & & 10 & 1 \\
\hline Lange-Bertalot & 20 & & 3.6 & & 3.7 & & 20 & 0.48 \\
\hline Achnanthidium minutissimum (Kützing) & & & & & & & & \\
\hline $\begin{array}{l}\text { Czarnecki } \\
\text { Achnanthidium pyrenaicum (Hustedt) }\end{array}$ & 61 & 25 & 17.1 & 26.8 & 29.5 & 8 & 60.8 & 0.16 \\
\hline $\begin{array}{l}\text { H.Kobayasi } \\
\text { Achnanthidium straubianum (Lange-Bertalot) }\end{array}$ & 6 & 9 & & 5.6 & 12.2 & 2 & 9.1 & 0.86 \\
\hline Lange-Bertalot & 10 & & & & 5.6 & & 10 & 1 \\
\hline $\begin{array}{l}\text { Adlafia minuscula (Grunow) Lange-Bertalot } \\
\text { Amphora copulata (Kützing) Schoeman \& }\end{array}$ & 10 & & & & 3.7 & & 10 & 1 \\
\hline R.E.M.Archibald & 10 & & & & 2.5 & & 10 & 1 \\
\hline Amphora indistincta Levkov & 67 & & 4 & & 4.1 & 1 & 66.9 & 0.01 \\
\hline $\begin{array}{l}\text { Amphora ovalis (Kützing) Kützing } \\
\text { Amphora pediculus (Kützing) Grunow ex }\end{array}$ & 10 & & & & 0.5 & & 10 & 1 \\
\hline A.Schmidt & 50 & & 13.6 & & 3.2 & & 50 & 0.04 \\
\hline Brachysira sp. & 10 & & & & 0.6 & & 10 & 1 \\
\hline Caloneis fontinalis (Grunow) Cleve-Euler & 10 & & 0.8 & & & & 10 & 1 \\
\hline Cocconeis placentula var. euglypta Ehrenberg & & 66 & & 30 & 0.6 & 15.2 & 66.4 & 0.01 \\
\hline Cocconeis pediculus Ehrenberg & & 11 & & & & 9.3 & 11.1 & 0.48 \\
\hline $\begin{array}{l}\text { Cocconeis placentula var. lineata (Ehrenberg) } \\
\text { van Heurck }\end{array}$ & 36 & 27 & 30.9 & 32.2 & 11.6 & 10.4 & 36.2 & 0.78 \\
\hline Cocconeis pseudolineata (Geitler) Lange- & & & & & & & & \\
\hline Bertalot & 51 & 6 & 9.5 & & 7.8 & 10.2 & 50.8 & 0.12 \\
\hline Cymatopleura solea (Brébisson) W.Smith 1851 & 10 & & 7.7 & & & & 10 & 1 \\
\hline Cymbella excisa Kützing & 11 & 5 & 0.6 & & 1.2 & 1.3 & 11.2 & 1 \\
\hline Cymbella tridentina Lange-Bertalot, & & & & & & & & \\
\hline M.Cantonati \& A.Scalfi & & 44 & & 21.6 & & 67.8 & 44.4 & 0.04 \\
\hline Diatoma mesodon (Ehrenberg) Kützing & 3 & 10 & 0.7 & 8.1 & 0.6 & & 9.6 & 0.88 \\
\hline Diploneis krammeri Lange-Bertalot \& & & & & & & & & \\
\hline E.Reichardt & 30 & & 7.7 & & 0.8 & & 30 & 0.21 \\
\hline Encyonopsis cesatii (Rabenhorst) Krammer & 10 & & 1.2 & & & & 10 & 1 \\
\hline Encyonopsis krammeri Reichardt & & 11 & & & & 2.0 & 11.1 & 0.48 \\
\hline Encyonopsis fonticola (Hustedt) Krammer & 10 & & & & 0.6 & & 10 & 1 \\
\hline Eolimna minima (Grunow) Lange-Bertalot & 20 & & 1.2 & & 5.2 & & 20 & 0.47 \\
\hline Epithemia argus (Ehrenberg) Kützing & 10 & & 4.3 & & & & 10 & 1 \\
\hline Epithemia frickei Krammer in Lange-Bertalot \& & & & & & & & & \\
\hline Krammer 1987 & & 22 & & 2.3 & & 2.5 & 22.2 & 0.22 \\
\hline Frustulia vulgaris (Thwaites) De Toni & 10 & & & & 0.6 & & 10 & 1 \\
\hline $\begin{array}{l}\text { Humidophila perpusilla (Grunow) Lowe, } \\
\text { Kociolek. Johansen, Van de Vijver. Lange- }\end{array}$ & & & & & & & & \\
\hline 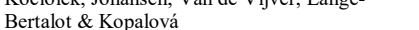 & 30 & & 2.4 & & 6 & & 30 & 0.22 \\
\hline Gomphonema pumilum (Grunow) Reichardt \& & & & & & & & & \\
\hline Lange-Bertalot & 5 & 25 & & 55 & 13 & 6.3 & 24.5 & 0.49 \\
\hline Gomphonema pumilum var. elegans & & & & & & & & \\
\hline E.Reichardt \& Lange-Bertalot & 59 & & 23.0 & 1 & 13.6 & 1 & 58.7 & 0.05 \\
\hline Gomphonema tergestinum (Grunow) Fricke & 10 & & 1.1 & & & & 10 & 1 \\
\hline Meridion circulare (Greville) C.Agardh & 15 & 31 & 2.7 & 4.27 & 3.9 & 13.5 & 31 & 0.66 \\
\hline Navicula antonii Lange-Bertalot & 20 & & 0.8 & & 2.5 & & 20 & 0.47 \\
\hline Navicula cariocincta Lange-Bertalot & 10 & & 0.8 & & & & 10 & 1 \\
\hline Navicula cryptotenella Lange-Bertalot & 10 & & 1.1 & & & & 10 & 1 \\
\hline Navicula radiosa Kützing & 10 & & & & 0.5 & & 10 & 1 \\
\hline Navicula tripunctata (O.F.Müller) Bory de & & & & & & & & \\
\hline Saint-Vincent & 10 & & & & 0.6 & & 10 & 1 \\
\hline Nitzschia dissipata (Kützing) Rabenhorst & 10 & & & & 0.6 & & 10 & 1 \\
\hline Nitzschia palea (Kützing) W.Smith & 18 & 1 & 30.8 & & 4.3 & 3.3 & 18.1 & 0.59 \\
\hline Nitzschia sigmoidea $($ Nitzsch) W.Smith & 10 & & 7.7 & & & & 10 & 1 \\
\hline Pinnularia subrupestris K. Krammer & 10 & & 7.7 & & & & 10 & 1 \\
\hline Planothidium dubium (Grunow) Round \& & & & & & & & & \\
\hline Bukhtiyarova & 30 & & 10.5 & & 1.1 & & 30 & 0.22 \\
\hline Planothidium frequentissimum (Lange-Bertalot) & & & & & & & & \\
\hline Round \& L.Bukhtiyarova & 20 & & 0.8 & & 0.3 & & 20 & 0.47 \\
\hline Planothidium lanceolatum (Brébisson $\mathrm{ex}$ & & & & & & & & \\
\hline Kützing) Lange-Bertalot & 74 & 2 & 19.8 & 0.9 & 12.9 & 8 & 74.4 & $\mathbf{0}$ \\
\hline Psammothidium grishunum (Wuthrich) & & & & & & & & \\
\hline L.Bukhtiyarova \& Round & 10 & & 1.5 & & & & 10 & 1 \\
\hline Rhoicosphenia abbreviata (C.Agardh) Lange- & & & & & & & & \\
\hline Bertalot & 13 & 19 & 5.7 & 9.8 & 1.0 & 2.1 & 18.5 & 0.84 \\
\hline Sellaphora pupula (Kützing) Mereschkovsky & 10 & & & & 0.6 & & 10 & 1 \\
\hline Stauroneis smithii Grunow & 10 & & 7.7 & & & & 10 & 1 \\
\hline Ulnaria ulna (Nitzsch) P.Compère & 1 & 40 & & 1.2 & 0.5 & 0.9 & 39.8 & 0.11 \\
\hline
\end{tabular}


The number of taxa per sample varied from 2 to 27, and Shannon - Wiener Diversity Index varied between 0.34 and 2.52, and it indicated low to moderately high species diversity.

Statistically important differences, using $\mathrm{t}$ test $(t=2.79 ; p=0.013)$, were established between values of Shannon - Wiener Diversity Index for spring habitats (in average $\mathrm{H}^{\prime}=1.67$ ) and Diversity Index values for stream habitats (in average $\left.\mathrm{H}^{\prime}=1.15\right)$. Based on 996 permutations, using Permutation of residuals under a reduced model (Permutational Manova test), it was proven that diatom assemblages in spring habitats differ from diatom communities in stream habitats (Pseudo $F=2.668$; $p=0.012$ ). The differences between summer and autumn samples were not statistical significant (Pseudo $F=0.586 ; \mathrm{p}=0.879$ ). Plot of nonmetric multidimensional scaling (nDMS) is shown on the Figure 1. According to IndVal analysis, spring samples were clearly different from stream samples with higher abundance of Planothidium lanceolatum, Amphora indistincta, Cocconeis placentula var. lineata and Gomphonema pumilum var. elegans $(\mathrm{p}<0.05)$. Seasonal variations on $\mathrm{nDMS}$ plot were indistinct. The only exception was spring GB, which is characterized by seasonal variation of discharge during the year. On this locality, 27 taxa were determined in the autumn, while in the summer only seven taxa were found with domination of species Nitzschia palea.

Stream habitats are quite heterogeneous, and they unclear grouped on the plot. Typical characteristics of stream samples were lower number of taxa and high values of abundance of several dominant taxa, such as Achnanthidium minutissimum (streams MI and TA), Cymbella tridentina (stream MI), Gomphonema pumilum (stream TA), Cocconeis placentula var. euglypta (streams TA and KA), Cocconeis placentula var. lineata (stream KE). 


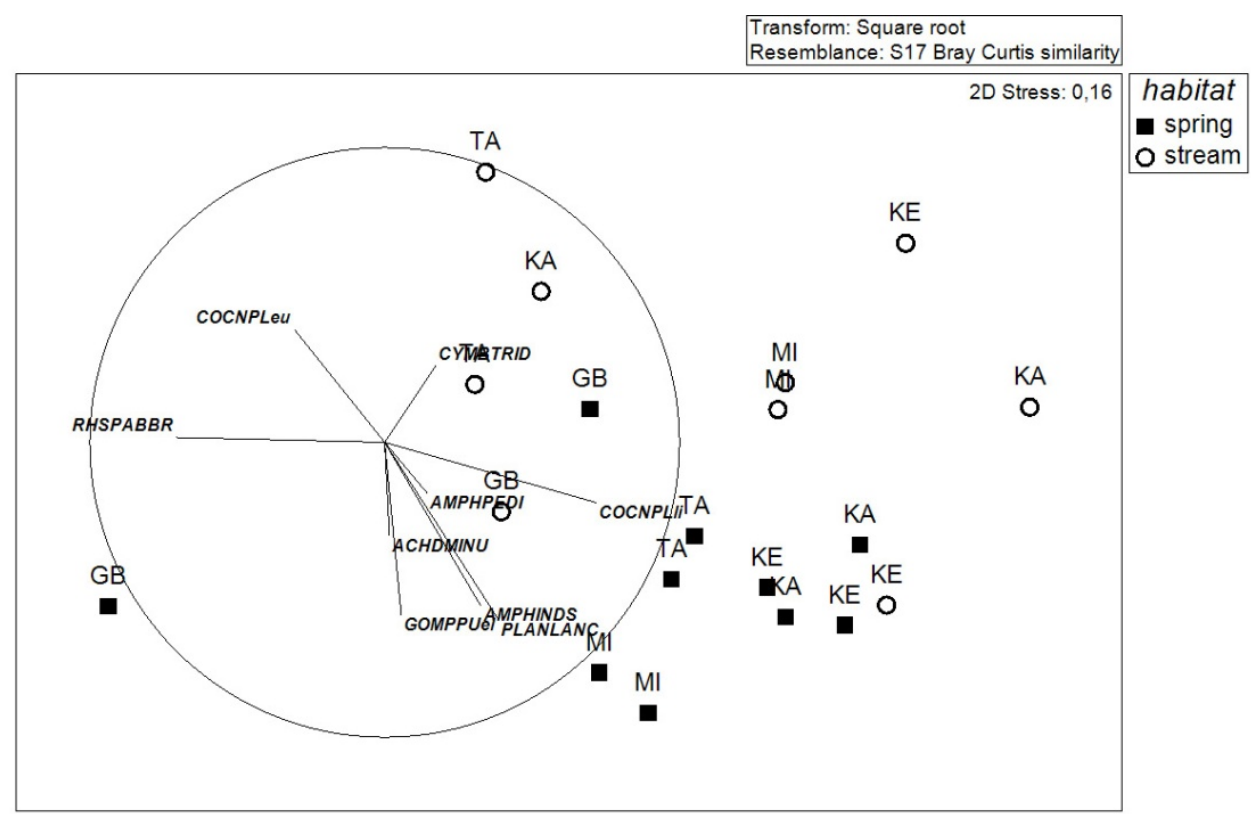

Figure 1. Nonmetric multidimensional scaling (nDMS) ordination of diatoms in 19 samples in 5 spring and 5 stream locality during investigation period. Acronym of the species with higher abundance or indicator species given by IndVal analysis: COCNPLeu - Cocconeis placentula var. euglypta, RHSPABBR - Rhoicosphenia abbreviata, CYMBTRID - Cymbella tridentina, COCNPLIi - Cocconeis placentula var. lineata, AMPHPEDI - Amphora pediculus, ACHDMINU - Achnanthidium minutissimum, GOMPPUel - Gomphonema pumilum var. elegans, PLANLANC - Planothidium lanceolatum, AMPHINDS - Amphora indistincta

Slika 1. Dijagram nemetričnog multidimenzionalnog skaliranja za dijatomejske zajednice u 19 uzoraka u pet izvora i pet potoka u periodu istraživanja. Akronimi vrsta s višim vrijednostima abundance ili indikatorske vrste dobivene IndVal analizom: COCNPLeu - Cocconeis placentula var. euglypta, RHSPABBR - Rhoicosphenia abbreviata, CYMBTRID - Cymbella tridentina, COCNPLIi - Cocconeis placentula var. lineata, AMPHPEDI - Amphora pediculus, ACHDMINU - Achnanthidium minutissimum, GOMPPUel - Gomphonema pumilum var. elegans, PLANLANC - Planothidium lanceolatum, AMPHINDS - Amphora indistincta

\section{DISCUSSION - Diskusija}

The performed investigation confirms the higher values of diatom species diversity in spring than in stream habitats, which is in accordance with the results of CANTONATI and PIP (2000) and SPITALE et al. (2012). These authors have compared longitudinal and seasonal differences in diatom assemblages in springs on contrasting lithology. Similar to their study results, high domination of rheobiont taxa downstream, such as A. minutissimum or Gomphonema pumilum sensu lato, was established during the investigated period. However, similarities of the identified diatom indicator species for spring habitats and downstream localities in this research were not found in comparison to the previous similar studies. This can be explained by 
heterogeneity and mosaicism of spring habitats, which had previously accentuated as very important characteristics of springs (CANTONATI et al. 2006). In opposite to conducted research and the results of above-mentioned authors' studies, SHERWOOD et al. (2000) report an increase in species richness of the algal and higher plant communities in a downstream direction. However, seasonal differences were indistinctive in their or other previous studies between summer and autumn sampling. Analyzing the taxonomic composition, most of the determined species have been typically found in spring habitats of Europe (CANTONATI 1998; ABOAL et al. 1998; FRANKOVÀ et al. 2009; WERUM and LANGE - BERTALOT 2004).

Very abundant species in the studied springs, for example epiphytic taxa Planothidium lanceolatum, Cocconeis placentula var. lineata were not so abundant in streams in this research. That can be caused by higher flow velocity and absence of mosses in stream habitats.

Most of the identified diatom species are widespread in the freshwater ecosystems, such as Achnanthidium minutissimum, Gomphonema pumilum and Nitzschia palea. Species Achnanthidium minutissimum is one of the most common diatoms in freshwater phytobenthic samples (KRAMMER and LANGE-BERTALOT 1991), and it occurs in the alkaline and acidic, oligotrophic and hypertrophic waters (ROUND 2004). Some very abundant species that we have found in studied springs in the Konjuh Mountain (Planothidium lanceolatum, Cocconeis pseudolineata, Cocconeis placentula var. lineata, Nitzschia palea) are indicators of mesotrophic and eutrophic water quality guided by VAN DAM et al. (1994). On the other hand, simultaneously in the same samples, typical crenophilous species such as Diatoma mesodon and Meridion circulare were identified. Comparing these two habitats, higher frequency of the species typical for small rheohelocrene springs such as Humidophila perpusilla, Diploneis krammeri, Encyonopsis cesatii (CANTONATi et al. 2012a) and many Navicula species were noted in the studied springs of Konjuh Mountain.

Comparing diatom assemblages from headwaters that inflow to the River Drinjača in this study with results for Drinjača lower course (SALKIĆ et al. 2012), the same four common species (Cocconeis placentula, Cymbella sp., Meridion circulare and Nitzschia sigmoidea) were identified.

Higher values of the Shannon-Wiener Diversity Index and a greater number of diatom species in springs in comparison with stream habitats indicate the purpose to preserve these rare and extremely endangered ecosystems, which can serve as refuge for endangered species of algae, especially diatoms.

Despite their small size, spring ecosystems are important refuge for preserving and conservation freshwater diatoms. Uncontrolled management and capturing of mountain springs, and modification of spring source into the fountain can result in the reduction of the diversity of rare taxa in the future. 


\section{REFERENCES - Literatura:}

Aboal, M., Puig, M. A. and Prefasi, M. (1998): Diatom assemblages in springs in Castellon province, Eastern Spain. Algological Studies 90. pp, 79 - 95.

ANDERSON, M.J. (2001): A new method for non-parametric multivariate analysis of variance. Austral Ecology, 26, pp, 32 - 46.

BLAGOJEVić, S. (1974): Razvoj perifitona u otvorenim uređajima vodovoda u krškim vrelima. Doktorska disertacija. Prirodoslovno-matematički fakultet, Sveučilište u Zagrebu. Zagreb.

BLAgOJEVić, S. (1976a): Prilog poznavanju cijanoficeja (Cyanophyceae) krških izvorišta. Acta Botanica Croatia, 35, pp, 207-215.

BLAgoJević, S. (1976b): Prilog poznavanju algi krških izvorišta u Bosni i Hercegovini. I. Chrysophyceae, Xanthophyceae, Bacillariophyceae. Godišnjak Biološkog instituta Univerziteta u Sarajevu, 29, pp, 5-21.

Cantonati, M. (1998): Diatom communities of springs in the Southern Alps. Diatom Research, 13(2), pp, $201-220$.

CANTONATi, M. and PiPP, E. (2000): Longitudinal and seasonal differentiation of epilithic diatom communities in the uppermost sections of two mountain springfed streams. Verhandlungen der Internationalen Vereinigung für theoretische und angewandte Limnologie 27, pp, 1591 - 1595.

CAntonati, M. and Spitale, D. (2009): The role of environmental variables in structuring epiphytic and epilithic diatom assemblages in springs and streams of the Dolomity Bellunesi National Park (south-eastern Alps). Fundamental and Applied Limnology, 174, pp, 117-133.

Cantonati, M., Gerecke, R. and Bertuzzi, E. (2006): Springs of the Alps - sensitive ecosystems to environmental change: from biodiversity assessments to long-term studies. Hydrobiologia, 562, pp, 59 - 96.

CANTONAti, M., FÜREDER, L., GeRECKE, R., JütTner, I. and Cox, E.J. (2012a): Crenic habitats, hotspots for freshwater biodiversity conservation: toward an understanding of their ecology. Freshwater Science, 31(2), pp, 463 - 480.

Cantonati, M., Angeli, N., Bertuzzi, E. and Spitale, D. (2012b): Diatoms in springs of the Alps: spring types, environmental determinants, and substratum. Freshwater Science, 31(2), pp, 499 - 524.

Cantonati, M., Rott, E., Spitale, D., Angeli, N. and JiŘi, K. (2012c): Are benthic algae related to spring types? Freshwater Science, 31(2), pp, 481 - 498.

CLARKE, K.R., WARWICK, R.M. (2001). Change in marine communities: an approach to statistical analysis and interpretation, 2nd edition. PRIMER-E, Plymouth, pp, 172.

Dedić, A., Plenković-Moraj A., KRalu Borojević K. and Hafner D. (2015): The first report on periphytic diatoms on artificial and natural substrate in the karstic spring Bunica, Bosnia and Herzegovina. Acta Botanica Croatica. 74 (2), pp, $393-$ 406. 
Delgado, C., Ector, L., Novais, M.H., Blanco, S., Hoffman, L. and Pardo, I. (2013). Epilithic diatoms of springs and spring-fed streams in Majorca Island (Spain) with the description of a new diatom species Cymbopleura margalefii sp. nov. Fottea, Olomouc 13(2), pp, 87-104.

DUFRENE, M. AND LEGENDRE, P. (1997): Species assemblages and indicator species: the need for a flexible asymmetrical approach. Ecological Monographs, 67, pp, 345366.

FrankovÀ, M., BoJkovÀ, J., PoulìckovÀ A. and HÀJEK. M. (2009): The structure and species richness of the diatom assemblages of the western Carpathian spring fens along the gradient of mineral richness. Fottea 9, pp, $355-368$.

GRANDIN, U. (2006): PC-ORD version 5: A user-friendly toolbox for ecologists. Journal of Vegetation Science 17, pp, 843-844.

GuirY, M.D. and GuirY, G.M. (2016): AlgaeBase. World-wide electronic publication, National University of Ireland, Galway. http://www.algaebase.org; searched on 9 December 2016.

Hofmann, G., Werum, M. and Lange-Bertalot, H. (2011): Diatomeen im Süßwasser Benthos von Mitteleuropa. Bestimmungsflora Kieselalgen für die ökologische Praxis. Über 700 der häufigsten Arten und ihre Ökologie. 3522 Fig. auf 133 Tafeln. 908 S. Ganter, Rugell.

Hustedt, F. (1930): Bacillariophyta. - In: A. Pascher (ed.): Die Süsswasserflora Mitteleuropas 10. - Jena.

KAMBERović, J. (2015): Struktura i sezonska dinamika krenonskih zajednica algi i vodenog bilja na području planine Konjuh. Doktorska disertacija. Prirodnomatematički fakultet. Univerzitet u Tuzli. Tuzla, Bosna i Hercegovina.

KAPETANOVić, T. and HAFNER, D. (2007): Diatoms of wet habitats in the subalpine belt of Mt. Vranica (Bosnia and Herzegovina) - In: Kusber,W.- H. i R. Jahn (eds.) (2007): Proceedings of the 1st Central European Diatom Meeting 2007 BerlinDahlem, 23-25 March: 73-78. BGBM Press, Berlin.

Kapetanović, T., JahN, R., Redžić, S. and CARić, M. (2011): Diatoms in a poor fen of Bijambare protected landscape, Bosnia \& Herzegovina. Nova Hedwigia 93.1-2, pp, 125-151.

Kelly, M. G., Cazaubon, A., Coring, E., Dell'uomo, A., Ector, L., Goldsmith, B., Guasch, H., Hu" RlimanN, J., JaRlman, A., KaWeCKA, B., KWANDRANS, J., Laugaste, R., Lindstrøm, E.A., Leitao, M., Marvan, P., Padisa' K.J., PipP, E., Prygiel, J., Rott, E., Sabater, S., Van dam, H. and Vizinet, J. (1998): Recommendations for the routine sampling of diatoms for water quality assessments in Europe. Journal of Applied Phycology 10, pp, 215-224.

KRAmmer, K. \& LANGe - BeRTAlot, H. (1986): Bacillariophyceae: Naviculaceae. In:Ettl, H., Gerloff, J., Heynig, H. \& Mollenhauer, D. (eds), Süßwasserflora von Mitteleuropa, vol. 2/1, pp. 1-876. Gustav Fischer Verlag, Sttutgart.

KRAMmer, K. \& LANGe - Bertalot, H. (1988): Bacillariophyceae: Bacillariaceae, Epithemiaceae, Surirellaceae. In: ETtL, H., GerlofF, J., HEYNIG, H. \& 
Mollenhauer, D. (eds), Süßwasserflora von Mitteleuropa, vol. 2/2, pp. 1-596. Gustav Fischer Verlag, Sttutgart.

KRAMMER, K. \& LANGE - BeRTALOT, H. (1991a): Bacillariophyceae: Centrales, Fragilariaceae, Eunotiaceae. In: EtTl, H., GERlofF, J., HeYNiG, H. \& MollenhaUeR, D. (eds), Süßwasserflora von Mitteleuropa, vol. 2/3, pp, 1-576. Gustav Fischer Verlag, Sttutgart.

KRAmmer, K. \& LANGE - BeRTAlOt, H. (1991b): Bacillariophyceae: Achnanthaceae, Kritische Ergänzungen zu Navicula (Lineolatae) und Gomphonema. Gesamtliteraturverzeichnis. In: EtTl, H., GerlofF, J., HeYNiG, H. \& MollenhaUER, D. (eds), Süßwasserflora von Mitteleuropa, vol. 2/4, pp, 1-437. Gustav Fischer Verlag, Sttutgart.

KRAmmeR, K. (2000): The genus Pinnularia. Diatoms of Europe, Volume 1. A.R.G. Gantner Verlag K.G. Florida. 703 pp.

KrammeR, K. (2002): Cymbella. Diatoms of Europe, Volume 3. A.R.G. Gantner Verlag K.G. Florida. 584 pp.

KRAMMER, K. (2001): Navicula sensu stricto 10 Genera Separated from Navicula sensu lato Frustulia. Diatoms of Europe, Volume 2. A.R.G. Gantner Verlag K.G. Florida. $526 \mathrm{pp}$.

LegendRe, P. and Legendre, L. (1998): Numerical Ecology. 2nd English edition. Elsevier, Amsterdam.

LOWE, L. R and PAN, Y. (1996): Benthic Algal Communities as Biological Monitors. In Stevenson, R. J., Bothwel, M.L. and Lowe, R. L. (eds). Algal Ecology. Freshwater Benthic Ecosystems, Academic Press, San Diego, pp, 705-739.

PouličKovÁ, A., HAŠLER, P. and KitNeR, M. (2005): Cyanobacteria and algae. - In: Poulíčková, A., Hájek, M. i Rybníček, K. (eds): Ecology and palaeoecology of spring fens of the West Carpathians (Monography), Palacký University, Olomouc. pp, 105-130.

Round, F.E. (2004): pH scaling and diatom distribution. Diatom 20, pp, 9-12.

SABATER, S. and ROCA, J. R. (1990): Some factors affecting distribution of diatom assemblages in Pyrenean springs. Freshwater Biology, 24, pp, 493-507.

SALKić, R., TROŽić-BOROVAC, S., SELIMOVIĆ, M., ŠKRIJELJ, R. AND HAFNER, D. (2014): Ecological status of rivers Drinjača. Works of the Faculty of Forestry University of Sarajevo, 1, pp, 45-55.

ShANnON, C. E. and WiEnER, W. (1949): The Mathematical Theory of Communication. The University of Illinois Press. Urbana.

SHERWOOD, A.R. and SHEATH, R.G. (1998): Seasonality of macroalgae and epilithic diatoms in spring-fed streams in Texas, USA. Hydrobiologia.

SHERWOOD, A.R., T.L. Rintoul, K.M. MüLLER and R.G. SHEATH. (2000): Seasonality and distribution of epilithic diatoms, macroalgae and macrophytes in a spring-fed stream system in Ontario, Canada. Hydrobiologia 435, pp, $143-152$.

Spitale, D., Lencioni, V. and CANTONATi, M. (2012): Relative importance of space and time in determining the biotic structure in the upper part of spring-fed streams. Freshwater Science, 31(2), pp, 586-598. 
Stevenson, J. (1996): Ecology in Freshwater Benthic Habitats. In Stevenson, R. J., Bothwel M.L. and Lowe, R. L. (eds). Algal Ecology. Freshwater Benthic Ecosystems, Academic Press, San Diego, pp, 3-30.

TAXBöCK, L. and PREisig., H.R. (2007): The diatom communities in Swiss springs: a first approach. Proceedings of the 1st Central European Diatom Meeting. - In Kusber, W-H. and Jahn R. (editors). Botanic Garden and Botanical Museum Berlin-Dahlem. Freie Universität Berlin, Berlin, Germany, pp,163-168.

VAn DAm, H., MeRTEnS, A. and SinKeldam, J. (1994): A coded checklist and ecological indicator values of freshwater diatoms from the Netherlands. Netherlands Journal of Aquatic Ecology 28(1), pp, 117-133.

Werum, M. and Lange-Bertalot, H. (2004): Diatoms in springs from central Europe and elsewhere under the influence of hydrogeology and anthropogenic impacts. Iconographia Diatomologica 13. A. R. G. Gantner Verlag K. G., Ruggell, Liechtenstein.

WOJTAL, A. and SOBCZYK, L. (2006): Composition and structure of epilithic diatom assemblages on stones of different size in a small calcareous stream (S Poland). Arch. Hydrobiol. Suppl. 162, Algol. Stud. 119, pp, 105-124. 


\section{SAŽETAK}

Izvori su prepoznati kao značajni refugiji važni za očuvanje biodiverziteta slatkovodnih biotopa. U radu je analiziran biodiverzitet i upoređivana je struktura epilitskih zajednica silikatnih algi između izvorišta i pripadajućih potoka na planini Konjuh (BiH). Uzorkovanje algi kremenjašica (silkatnih) i mjerenje osnovnih fizičkohemijskih parametara na terenu provedeno je na pet manjih planinskih tekućica, pri čemu su uzorkovana izvorišna područja i njima pripadajući gornji tokovi tekućica $u$ ljetnoj i jesenjoj sezoni tokom 2013. godine. Epiliton je uzorkovan standardnom metodologijom prema Kelly i sar. (1998). U laboratoriju su izrađeni i pregledavani trajni preparati silikatnih algi uklopljeni u Naphrax, pri čemu je određivana relativna abundanca vrsta brojanjem do 400 frustula. Utvrđeno je da su izvorska staništa brojnija i raznovrsnija vrstama (srednja vrijednost $H^{\prime} \log _{\mathrm{e}}=1,67$ ), a $t$ testom je potvrđeno da se vrijednosti Shannon-Wienerovog indeksa diverziteta statistički značajno razlikuju u poređenju sa staništima gornjih tokova potoka (srednja vrijednost $\left.H^{\prime} \log _{\mathrm{e}}=1.15 ; t=2.79 ; p=0.013\right)$. Sličnosti u strukturi zajednica s različitih lokaliteta istraživane su metodom nemetričnog multidimenzionalnog skaliranja, baziranom na Bray-Curtis indeksu sličnosti. Upotrebom permutacijskog Manova testa, dokazano je da postoji razlika u strukturi zajednica izvora i potoka (Pseudo $\mathrm{F}=2.66, p=0.012$ ), dok razlika u strukturi zajednica između ljetne i jesenje sezone statistički nije potvrđena (Pseudo $\mathrm{F}=0.586, p=0.876$ ). Najfrekventnije i najabundantnije vrste u uzorcima izvora bile su: Achnanthidium minutissimum (Kützing) Czarnecki, Cocconeis pseudolineata (Geitler) Lange-Bertalot, Gomphonema pumilum var. elegans E.Reichardt \& Lange-Bertalot, Meridion circulare (Greville) C.Agardh i Planothidium lanceolatum (Brébisson ex Kützing) Lange-Bertalot. Najfrekventnije i najdominantnije u staništima potoka su bile: Achnanthidium minutissimum (Kützing) Czarnecki, Cocconeis placentula var. euglypta (Ehrenberg) Grunow, Cocconeis placentula var. lineata (Ehrenberg) van Heurck i Cymbella tridentina Lange-Bertalot, M.Cantonati \& A.Scalfi. Izvori su heterogena staništa sa specifičnom florom dijatomeja i imaju stabilniji tok vode u odnosu na potoke. Iako su površinom jako mala područja, diverzitet vrsta koji ih nastanjuje ne smije biti zanemarivan prilikom planiranja upotrebe ovih prirodnih resursa.

Ključne riječi: diverzitet, epiliton, dijatomeje, izvorišna područja, Konjuh planina $(\mathrm{BiH})$

Corresponding author: Jasmina Kamberović, University of Tuzla, Faculty of Natural Sciences and Mathematics, Department of Biology, Univerzitetska 4, 75000, Tuzla, Bosnia and Herzegovina, e mail: jasmina.kamberovic@untz.ba 